\title{
Relationship of Farmers Profile with Utilization of Extension Services
}

\author{
B. Neethi* and A. Sailaja \\ Department of agricultural extension, college of agriculture, Acharya N.G Ranga Agriculture \\ University, Rajendranagar, Hyderabad, India \\ *Corresponding author
}

A B S T R A C T

\begin{abstract}
Ex-post facto research design was followed for carrying out the study in the state of Andhra Pradesh. Sample comprised of 120 farmers selected randomly from four randomly selected mandals of Mahaboobnagar district which was a purposive selection. Age, education, farm size, farming experience, annual income, occupation, innovativeness, economic orientation, market orientation, change proneness, achievement motivation, information seeking behavior, social participation and participation in activities of extension centre (District Agricultural Advisory Transfer of Technology Centre) were the profile characteristics of farmers studied under independent variables in the study. Utilisation of services was the dependent variable selected for the study. The findings revealed that majority of farmers were illiterate, middle aged, possessed small farm size, had medium farming experience, annual income, labour and agriculture was their main and subsidiary occupation, medium innovativeness, medium economic orientation, medium market orientation, medium change proneness, medium achievement motivation, medium information seeking behavior, with no membership in any social organization and medium participation in DAATTC activities respectively. The profile characteristics like age, education, farm size, farming experience, annual income, innovativeness, market orientation, change proneness, information seeking behaviour, social participation and participation in DAATTC activities were positively and significantly correlated with the utilisation of DAATTC services by farmers. Hence, above variables should be taken into consideration for selection of master trainers and innovative farmers so that these farmers can effectively communicate to fellow farmers resulting in effective service utilisation.
\end{abstract}

\begin{tabular}{|l|}
\hline Ke y w or d s \\
Relationship, \\
Farmers profile, \\
Utilization, \\
Extension services \\
\hline Article Info \\
\hline Accepted: \\
20 April 2018 \\
Available Online: \\
10 May 2018 \\
\hline \hline
\end{tabular}

\section{Introduction}

India is predominantly an agricultural country. More than 70.00 per cent of the Indian population directly depends on agriculture for their livelihood. The main policy of Indian Agriculture has been to grow more food to meet the demands of the ever growing population since independence. Hardly, any effort has gone towards post-harvest management and valve addition. To meet upcoming challenges of World Trade Organisation, we should not only produce more, but also aim at improving the quality and capability of the production system.

The Acharya N.G Ranga Agricultural University (ANGRAU) has been bestowed with the responsibility of teaching, research and extension education and therefore, it has 
to effectively utilise its human resources to transfer the technologies developed by its research personnel to the farmers' fields, to improve productivity and to generate higher income to the farmers. The university fulfills its mandate through integrated programme of education, research and extension units located across the state.

The Extension services of ANGRAU are being offered through six extension centres. They are DAATTCs, Krishi Vigynan Kendras (KVKs), Agricultural Information and Communication Centre (AI\&CC), Agricultural Technology Information centre (ATIC), Electronic media wing and Extension Education Institute (EEI).

An attempt is also made to study the relationship between profile characteristics of farmers and service utilisation in order to formulate a strategy in effective delivery of services to enable effective utilisation by farmers, thus it serves as ready - reckoner for ANGRAU planners to put forth the strategy into implementation and thus the farming community.

\section{Materials and Methods}

Ex-post facto research design was followed for carrying out the study in the state of Andhra Pradesh. Sample comprised of 120 farmers selected randomly from four randomly selected mandals of Mahaboobnagar district which was a purposive selection.

Age, education, farm size, farming experience, annual income, occupation, innovativeness, economic orientation, market orientation, change proneness, achievement motivation, information seeking behavior, social participation to participation in activities of extension centre (District Agricultural Advisory Transfer of Technology Centre) were the profile characteristics of farmers studied under independent variables in the study. Utilisation of services was the dependent variable selected for the study. Relevant seales and schedules have been used to study these independent variables. The utilization of extension services by farmers which was measured with an index developed was related with these profile characteristics using coefficient of correlation.

\section{Results and Discussion}

From the Table 1, it was found that majority $(40.00 \%)$ of the respondents were categorized into middle age group followed by old age group (33.33\%) and rest of them (26.67\%) were of young age.

It could be concluded that middle age respondents dominated the sample with their occupation being labour and agriculture as main and subsidiary occupation. The reason for the above trend was due to the migration of young people to towns and cities for higher education and business, which was also supported in the study as that more than half of respondents pursued agriculture and other subsidiary occupation like business, services and caste based occupation. Hence, Government and Department of Agriculture should ensure more profitability in agriculture, so as to make agriculture more remunerative to youth in villages so that they adopt farming as their profession. This is in conformity with the results by Sudhakar (2002), Savitha (2001), Sunil et al., (2009) and Meena (2010).

\section{Education}

It was known that majority of the respondents were illiterate $(38.33 \%)$ followed by primary school (15.00\%), middle school (14.17\%), functionally literate (13.33\%), high school $(10.00 \%)$, intermediate $(5.00 \%)$, under graduation $(2.50 \%)$ and post-graduation and above $(1.67 \%)$ respectively. 
It could be known that medium annual income, lack of awareness among the farmers about the importance and need of education and also dire necessity in the family to help their parents were the reasons for poor formal schooling among the respondents. As a result they did not send their children for pursuing higher education. As most of the higher educational facilities were available far away from the villages, school dropout is still the problem especially after the middle school level. The results were in conformity with that of Prasad (1997), Veerendranath (2000) and Aghazia (2008).

\section{Farm size}

It could be indicated that majority $(26.67 \%)$ of the respondents were grouped under small farm size followed by semi-medium (25.83\%), medium (20.00\%) large farm size (15.83\%) and marginal $(11.67 \%)$ respectively.

It can be inferred that majority of farmers had small followed by semi-medium farm size. This was due to the fact that the fragmentation of land holding from generation to generation which led most of large holding farmers turning to small and medium holding farmers. These findings were in line with the findings of Rajarathnam (2000), Rahul (2003), Sagar and Vijay (2004), Gopinath (2005) and Archana (2012).

\section{Farming experience}

It could be indicated that majority (48.33\%) of the respondents were grouped under medium farming experience followed by high $(28.33 \%)$ and low $(23.33 \%)$ respectively.

As majority of respondents were of middle age so was their farm experience also. Definitely the farming experience is an important factor which influences the farmers to accept, evaluate and experiment the innovative technologies in their farm. To enable them to effectively utilise their farm experience, the scientists and extension agencies have to conduct extension activities like trainings, result demonstrations, method demonstrations, meetings, exposure visits and group discussions so as to provide wide exposure to farmers and facilitate them to act further. This is in conformity with the results of Rajaratnam (2000), Gopinath (2005) and Archana (2012).

\section{Annual income}

It was found that majority (40.83\%) of respondents had medium followed by low $(17.50 \%)$, very low (16.67\%), high $(15.00 \%)$ and very high $(10.00 \%)$ annual income respectively.

Thus, it could be concluded that majority of the respondents had medium annual income. It was due to small farm size, medium innovativeness, medium economic orientation, medium market orientation, medium change proneness, medium achievement motivation and medium information seeking behaviour as indicated in the study. The same result was generated by Nagabhushana (2007) and Thoke and Gunjal (2009).

\section{Occupation}

It could be seen that majority $(49.17 \%)$ of respondents belonged to labour (in own land, hired) + agriculture group followed by 22.50 per cent who belonged to agriculture + caste occupation group, 11.67 per cent belonged to agriculture + service group and 11.67 per cent belonged to agriculture + business groups respectively.

It could be inferred that majority of the respondents belonged to labour + agriculture group. It was due to the reason that most of farmers being in middle age group and with 
small farm size and medium income did entire cropping operations on their own. The same result was generated by Babu (1992).

\section{Innovativeness}

It could be indicated that majority $(56.67 \%)$ of the respondents had medium innovativeness followed by low (25.00\%) and high (18.33\%) respectively.

This finding was clearly evident from medium level of information seeking behaviour, participation in DAATTC activities, social participation and extent of adoption of respondents. The same result was generated by Gopinath (2005) and Archana (2012).

\section{Economic orientation}

It could be revealed that majority $(48.33 \%)$ of the respondents possessed medium economic orientation followed by low $(41.67 \%)$ and high $(10.00 \%)$ respectively.

This result was also supported through the finding as revealed in Table 1 that the respondents ranked fourth in utilisation of technologies disseminated through DAATTC in terms of costs and profits. Hence, they did not have much orientation towards profit maximization in farming. It was also evident from the results that "A farmer should work towards more yields and greater profits" was ranked first followed by "A farmer should utilise different technologies to increase profits in comparison to single technology for his betterment" due to their medium economic orientation. The statement on "A farmer should try traditional technology in farming which may not earn him money" was least preferred by respondent farmers. Hence, it could be said that farmers have exhibited readiness towards modern technologies and need to be convinced to act further. The same result was generated by Madhushekar (2009).

\section{Market orientation}

It could be indicated that majority $(45.83 \%)$ of the respondents had medium level of market orientation followed by high $(30.83 \%)$ and low $(23.33 \%)$ levels respectively.

\section{Change proneness}

It was found that majority $(49.17 \%)$ of respondents had medium change proneness followed by low (26.67\%) and high $(24.17 \%)$ respectively.

This finding was supported by medium innovativeness, medium extent of adoption and medium participation of respondents in DAATTC activities in the study. Moreover majority of respondents disagreed on the statement "traditional ways of farming are best" which implies that they have faith in modern practices and also they disagreed on the statement like "often new technologies are not successful, however if they are promising, farmers would surely utilise them" which indicated that the farmers were ready to adopt any new farm practice if proved successful. They also agreed to be "cautious about trying the new technologies" all these indicated that they wanted to practice only the proven technologies. Hence, respondents were prone to change to meet the challenging demands and needs of clientele in this fast changing society. The same result was generated by Vasantha (1996).

\section{Achievement motivation}

It was found that majority $(51.67 \%)$ of respondents had medium level of achievement motivation followed by low (30.83\%) and high $(17.50 \%)$ levels respectively. It was revealed that majority of respondents had medium level of achievement motivation due to medium innovativeness and medium information seeking behaviour. 
Table.1 Distribution of respondents based on their profile characteristics

\begin{tabular}{|c|c|c|c|}
\hline \multirow[b]{2}{*}{ S. No. } & \multirow[t]{2}{*}{ Category } & \multicolumn{2}{|c|}{ Respondents } \\
\hline & & Frequency & Percentage (\%) \\
\hline \multirow[t]{4}{*}{1} & Age: & & \\
\hline & Young & 32 & 26.67 \\
\hline & Middle & 48 & 40 \\
\hline & Old & 40 & 33.33 \\
\hline \multirow[t]{9}{*}{2} & Education & & \\
\hline & Illiterate/ No schooling & 46 & 38.33 \\
\hline & Functionally literate & 16 & 13.33 \\
\hline & Primary school (up to 5th class) & 18 & 15 \\
\hline & Middle school (6th to 7th class) & 17 & 14.17 \\
\hline & High school $(8,9 \& 10$ th class $)$ & 12 & 10 \\
\hline & Intermediate & 6 & 5 \\
\hline & Under graduation & 3 & 2.5 \\
\hline & Post graduation and above & 2 & 1.67 \\
\hline \multirow[t]{6}{*}{3} & Farm size & & \\
\hline & Marginal & 14 & 11.67 \\
\hline & Small & 32 & 26.67 \\
\hline & Semi-medium & 31 & 25.83 \\
\hline & Medium & 24 & 20 \\
\hline & Large & 19 & 15.83 \\
\hline \multirow[t]{4}{*}{4} & Farming experience & & \\
\hline & Low & 28 & 23.33 \\
\hline & Medium & 58 & 48.34 \\
\hline & High & 34 & 28.33 \\
\hline \multirow[t]{6}{*}{5} & Annual income & & \\
\hline & Very low & 20 & 16.67 \\
\hline & Low & 21 & 17.5 \\
\hline & Medium & 49 & 40.83 \\
\hline & High & 18 & 15 \\
\hline & Very high & 12 & 10 \\
\hline \multirow[t]{5}{*}{6} & Occupation & & \\
\hline & Labour and agriculture & 59 & 49.17 \\
\hline & Agriculture and caste occupation & 27 & 22.5 \\
\hline & Agriculture and business & 14 & 11.67 \\
\hline & Agriculture and service & 20 & 16.66 \\
\hline \multirow[t]{4}{*}{7} & Innovativeness & & \\
\hline & Low & 30 & 25 \\
\hline & Medium & 68 & 56.67 \\
\hline & High & 22 & 18.33 \\
\hline
\end{tabular}




\begin{tabular}{|c|c|c|c|}
\hline 8 & Economic orientation & & \\
\hline & Low & 50 & 41.67 \\
\hline & Medium & 58 & 48.33 \\
\hline & High & 12 & 10 \\
\hline \multirow[t]{4}{*}{9} & Market orientation & & \\
\hline & Low & 28 & 23.33 \\
\hline & Medium & 55 & 45.84 \\
\hline & High & 37 & 30.83 \\
\hline \multirow[t]{4}{*}{10} & Change proneness & & \\
\hline & Low & 32 & 26.66 \\
\hline & Medium & 59 & 49.17 \\
\hline & High & 29 & 24.17 \\
\hline \multirow[t]{4}{*}{11} & Achievement motivation & & \\
\hline & Low & 37 & 30.83 \\
\hline & Medium & 62 & 51.67 \\
\hline & High & 21 & 17.5 \\
\hline \multirow[t]{4}{*}{12} & Information seeking behaviour & & \\
\hline & Low & 21 & 17.5 \\
\hline & Medium & 68 & 56.67 \\
\hline & High & 31 & 25.83 \\
\hline \multirow[t]{6}{*}{13} & Social participation & & \\
\hline & No membership in any organization & 53 & 44.17 \\
\hline & Membership in one organization & 39 & 32.5 \\
\hline & $\begin{array}{l}\text { Membership in more than one } \\
\text { Organization }\end{array}$ & 16 & 13.33 \\
\hline & Office bearer & 5 & 4.17 \\
\hline & Public leader & 7 & 5.83 \\
\hline \multirow[t]{4}{*}{14} & $\begin{array}{l}\text { Overall participation in DAATTC } \\
\text { activities }\end{array}$ & & \\
\hline & Low & 41 & 34.17 \\
\hline & Medium & 61 & 50.83 \\
\hline & High & 18 & 15 \\
\hline
\end{tabular}

Table.2 Distribution of respondents based on their utilisation of DAATTC services

\begin{tabular}{|c|}
\hline S. No. \\
\hline 1 \\
\hline 2 \\
\hline 3 \\
\hline
\end{tabular}

\begin{tabular}{|c|}
\hline Category \\
\hline Low \\
\hline Medium \\
\hline High \\
\hline
\end{tabular}

\begin{tabular}{|c|c|}
\hline \multicolumn{2}{|c|}{ Respondents } \\
\hline Frequency & Percentage (\%) \\
\hline 21 & 17.50 \\
\hline 75 & 62.50 \\
\hline 24 & 20.00 \\
\hline
\end{tabular}


They also ranked second in utilisation of field days (Table 2). Moreover, field days are used to motivate the farmers to group psychology and adopt the practice by showing its performance by better profits. The same result was generated by Sunil et al., (2009).

\section{Information seeking behavior}

It could be indicated that majority $(56.67 \%)$ of the respondents had medium information seeking behaviour followed by high $(25.83 \%)$ and low $(17.50 \%)$ respectively. This was due to the fact that majority of respondents were illiterates which led to high dependence on informal sources followed by formal and mass media. This can also be related to poor educational levels, which inhibited them to contact other information sources. The same result was generated by Gangadhar (2009).

\section{Social participation}

It could be indicated that majority of (44.17\%) farmers had no membership in any organization followed by 32.50 per cent who had membership in one organization, 13.33 per cent of them had membership in more than one organization, 5.83 per cent belonged to public leaders category and 4.17 per cent were office bearers in the order of priority.

An examination from results revealed that larger portion of the respondents had no membership in any organization. This was because of inactive social organizations in the villages which were also evident in the study through their less dependence on local leaders and sarpanch for obtaining farm information. These findings were in line with the results of Veerendranath (2000).

\section{Participation in DAATTC activities}

It could be indicated that majority $(50.83 \%)$ of the respondents had medium participation in DAATTC activities followed by low $(34.17 \%)$ and high $(15.00 \%)$ respectively.

Majority of the respondents had medium participation in DAATTC activities. This result could be supported from the findings wherein majority of respondents had medium participation in exhibitions (45.83\%) and training programmes $(43.34 \%)$ respectively. Majority of respondents had low participation in kisan melas $(52.50 \%)$, listening / reading to information presented through mass media (46.66\%), visiting the information centre $(42.50 \%)$, field days $(40.83 \%)$, refinement of technologies $(37.50 \%)$ and study tours $(35.83 \%)$ respectively.

\section{Utilisation of DAATTC services}

It could be indicated from the Table 2 that majority $(62.50 \%)$ of the respondents had medium utilisation of DAATTC services followed by high $(20.00 \%)$ and low $(17.50 \%)$ utilisation of DAATTC services.

\section{Relationship of profile characteristics of farmers with utilisation of services}

The calculated values of age, education, farm size, occupation, innovativeness, market orientation, change proneness, social participation and participation in DAATTC activities were greater than table ' $r$ ' value at 5 per cent level of probability, whereas the calculated ' $r$ ' value is greater than tabled ' $r$ ' value at 1 per cent level of probability in case of farming experience, annual income and information seeking behaviour. Hence, null hypothesis was rejected and empirical hypothesis was accepted. Therefore, it can be concluded that there was significant relationship between above characteristics and utilisation of services. On the other hand the calculated ' $r$ ' values of economic orientation and achievement motivation were less than tabled ' $r$ ' value. Hence null 
hypothesis was accepted and empirical hypothesis was rejected. Therefore, it can be concluded that there was no significant relationship between above characteristics and utilisation of services.

The positive and significant relationship between utilisation of services and profile characteristics of farmers like age, education, farm size, farming experience, annual income, occupation, innovativeness, market orientation, change proneness, information seeking behaviour, social participation and participation in DAATTC activities was due to the reason that as age and education increases an individual encounters many situations, there by his comprehension ability enhances and mental horizons will be widened hence, their relationship. As majority of farmers had small farm size and medium utilisation, it could be said with increase in farm size, utilisation of services also increases as it enable him to better experience the situations. As the farming experience increases, he will be exposed to various situations, witnesses many extremes experienced various conditions and all these have empowered the farmers and thereby more the utilisation of services. From the findings, it was known that with increase in income, utilisation of services increases. This was clear through medium level of income, medium adoption and medium utilisation in the study. Thus, he can afford to reach the place of service and avail the service rendered.

Occupation was the next variable which was found to have positive and significant relation with utilisation. Nearly fifty per cent of farmers occupation was labour + agriculture in the study. This clearly shows that only farmers those who had farm based livelihoods were using services of DAATTC. Innovativeness of the respondents had positive and significant relationship with utilisation of services. This was due to reason that an individual with high innovativeness has desire to seek change in farming techniques and introduce changes in the farming. This desire makes him to acquire innovations directly from DAATTC scientists in terms of utilisation of services. Market orientation of the respondents was positive and significant relationship with utilisation of services. This indicates that an orientation towards markets and facilities enhances his utilisation. Moreover they have also suggested provision of ware houses on rent basis. In this connection, the DAATTC scientists had to provide more guidance on grading the produce at farmers level and also on selection of crops and varieties according to the market demand.

Change proneness and social participation were found to have positive and significant relationship with utilisation of services. As majority of respondents were found to have no membership in any organisation at village level, they had medium change proneness. Hence, change proneness was found to have positive and significant relationship with utilisation. The information seeking behaviour influences the respondents towards agricultural production and new management practices which in turn increases the utilisation of services. Farmers who have high level of information seeking behaviour have better chance to utilise services and hence the relationship. Participation in DAATTC activities of the respondents was found to have positive and significant relationship with utilisation. The possible reason for the above relationship was evident in the findings which indicated that the respondents had medium participation in DAATTC activities which led to improvement in their behavioural components.

Participation in DAATTC activities of respondents was found have no significant 
relationship with extent of adoption in cotton. This can be attributed to usage of their experience in adoption of technologies in other crops, other than the crop under study.

University technologies were disseminated by DAATTC scientists and other stakeholders to farmers. This system restricted only to Research-Extension-Farmer linkages so the linkages should be extended further to market for provision of market intelligence as majority of farmers of farmers had medium market orientation.

It observed from the study that majority of the respondents had middle age. In order to attract youth into the farming success stories had to be created at village level. Majority of the respondents of the study were illiterates. Hence, steps are to be taken to improve their literacy level by utilising the literate respondents of village (beneficiaries of sarva siksha abhiyan). Organizing adult literacy campaigns or linking them with agricultural programmes helps in better utilisation of agricultural technologies.

As majority of respondents had small farm size with medium income with labour and agriculture as main and subsidiary source of income, DAATTC scientists need to focus on promotion of farming system approach for betterment of their livelihood.

Majority of respondents had medium innovativeness, medium market orientation, medium change proneness, medium achievement motivation, medium information seeking behavoiur, and medium participation in DAATTC activities. Hence, there is a need to improve these characteristics from present level of medium to high level by intensifying the efforts through various ways of technology transfer like diagnostic visits, demonstrations and group meetings which recorded higher participation of respondents.
Majority of respondents were not members in any organization so extension agencies should encourage the farmer's social participation by strengthening community organization programmes to form youth clubs, welfare associations, farmer's discussion groups etc. so that they will get more exposure and empowered and effectively utilise the services.

Majority of respondents had medium utilisation of services of DAATTC. As there was less utilisation of services through assessment and refinement of technologies and services through information centre and supply of information material, the scientists need to assess and refine the technologies immediately and give feed back to farmers, so that the farmers get satisfied. To develop the information centre and supply the information material, sufficient budget has to be sanctioned so that technologies get widely publicized these will ultimately result in effective service utilisation.

The government should sensitize the farmers to involve formally in various rural organizations like panchayat, youth clubs, water users associations, community libraries and market committee etc. to improve their level of confidence and risk receptivity which enhance their adoption towards technologies.

The profile characteristics like age, education, farm size, farming experience, annual income, innovativeness, market orientation, change proneness, information seeking behavoiur, social participation and participation in DAATTC activities were positively and significantly correlated with the utilisation of DAATTC services by farmers. Hence, above variables should be taken into consideration for selection of master trainers and innovative farmers so that these farmers can effectively communicate to fellow farmers resulting in effective service utilisation. 


\section{References}

Aghazia. 2008. Training needs of onion cultivators in Afghanistan. M.Sc. (Ag.) Thesis. Acharya N.G. Ranga Agricultural University, Hyderabad, India.

Archana, P. 2012. A study on farmers' adaptability to climate variability in castor in Mahabubnagar district of Andhra Pradesh. M.Sc. (Ag.) Thesis. Acharya N.G. Ranga Agricultural University, Hyderabad, India.

Atchutaraju, K. 1998. Training needs of Betelvine farmers in Guntur district of Andhra Pradesh. M.Sc. (Ag.) Thesis. Acharya N.G. Ranga Agricultural University, Hyderabad, India.

Babu, B. 1992. A Study on training needs of tribal farmers with respect to mango cultivation in Khammam district of Andhra Pradesh. M.Sc. (Ag.) Thesis. Acharya N.G. Ranga Agricultural University, Hyderabad, India.

Gangadhar, J. 2009. Marketing behaviour of cotton farmers in Warangal District of Andhra Pradesh. M.Sc. (Ag.) Thesis. Acharya N.G. Ranga Agricultural University, Hyderabad, India.

Gopinath, M. 2005. Knowledge and adoption of Bengalgram farmers in Kurnool district of Andhra Pradesh. M.Sc. (Ag.) Thesis. Acharya N.G. Ranga
Agricultural University, Hyderabad, India.

Madhushekar, B.R. 2009. A study on marketing behaviour of chilli growers in Guntur district of Andhra Pradesh. M.Sc. (Ag.) Thesis. Acharya N.G. Ranga Agricultural University, Hyderabad, India.

Meena, M.S. 2010. Socio-economic study of organic farming in irrigated North Western Plain zone of Rajasthan. Agricultural Science Digest. 30: 94-97.

Nagabhushana, K.B. 2007. Farm performance of potato cultivators of Hassan district in Karnataka. M.Sc. (Ag.) Thesis. Acharya N.G. Ranga Agricultural University, Hyderabad, India.

Prasad, S.V. 1997. A critical analysis of diffusion and adoption of production recommendations of rainfed castor in Nalgonda district of Andhra Pradesh. Ph. D Thesis. Acharya N.G. Ranga Agricultural University, Hyderabad, India.

Rajarathnam, T. 2000. Impact of sunflower on farm extension demonstrations in Kurnool district of Andhra Pradesh. M.Sc. (Ag.) Thesis. Acharya N.G. Ranga Agricultural University, Hyderabad, India.

Savitha, B. 2001. Functioning of rythubazars in Ranga Reddy district of Andhra Pradesh. M.Sc. (Ag.) Thesis. Acharya N.G. Ranga Agricultural University, Hyderabad, India.

\section{How to cite this article:}

Neethi, B. and Sailaja, A. 2018. Relationship of Farmers Profile with Utilization of Extension Services. Int.J.Curr.Microbiol.App.Sci. 7(05): 2692-2701. doi: https://doi.org/10.20546/ijcmas.2018.705.312 